Article

\title{
The Effect of Pine Forest Structure on Bird-Mobbing Behavior: From Individual Response to Community Composition
}

\author{
Uzi Dagan and Ido Izhaki * \\ Department of Evolutionary and Environmental Biology, University of Haifa, Haifa 3498838, Israel \\ * Correspondence: izhaki@research.haifa.ac.il; Tel.: +972-4-8249025
}

Received: 5 August 2019; Accepted: 28 August 2019; Published: 3 September 2019

\begin{abstract}
Pine-forest bird communities are affected by the forest structure and the density and composition of its understory vegetation. In this study, we focused on the combined effects of vegetation structure and caller identity on the mobbing behavior of birds in breeding and non-breeding seasons. We examined the effect of the understory structure and the density of three types of conifer forest habitats on bird behavior by broadcasting three different types of mobbing calls: Those of two all-year resident species in the state Israel (Sardinian warbler Sylvia melanocephala Gmelin and great tit Parus major L.) and one European species (coal tit Periparus ater L.), which is absent from these habitats. The mobbing call attracted 689 birds of 17 species, which represented $31 \%$ to $95 \%$ of the forest bird species that we detected in point counts at the same study plots. Bird reactions to mobbing calls were affected by the status and season, depending on forest type. Our results show that responses were stronger in forests with developed understory in comparison to forests with no understory, especially in winter. The highest number of responders and highest species richness of responders were observed in winter. P. major calls generated more interspecific than intraspecific responses, whereas $S$. melanocephala calls generated equal levels of inter- and intraspecific reactions. Both species generated different response patterns across the three forest habitat types. The response level of responders is higher when the mobbing calls are issued by local species rather than the P. ater. In winter, the response of non-resident species was higher than of resident species. Based on these results, we encourage the managers to maintain well-established understory vegetation, with special attention to the shrubs layer, to promote species diversity and rich behavioral responses of birds in the conifer forests in the eastern Mediterranean region.
\end{abstract}

Keywords: pine forest; plantation; understory; vegetation; bird behavior; mobbing; bird community; habitat structure

\section{Introduction}

\subsection{Forest Structure, Bird-Community Structure, and Bird Behavior}

Forest habitat structure affects bird's community composition and biodiversity [1]. Studies demonstrated that the structure of forest vegetation governs bird abundance [2,3], community structure [4,5], and richness [6]. Furthermore, bird species diversity is also determined by vegetation structure in temperate coniferous forest $[7,8]$, deciduous forests [5,9], evergreen oak forests $[10,11]$, as well as in forest plantations [12-14].

There are several factors related to vegetation structure that increase the species richness and diversity of forest birds, such as plantation size [6,15], forest age [6,11], plant species richness [6,16], successional stage [6], understory composition [6], and canopy height [15]. As forests become denser 
with taller growing shrubs, trees, and climbers, they support higher bird densities $[17,18]$ and diversity [19].

The impact of vegetation structure on bird behavior, such as foraging and habitat selection, has been largely overlooked [20], especially in coniferous forests. Therefore, there is little empirical evidence on the effect of vegetation structure in pine forests on the ecological behavior of birds.

\subsection{Vigilance in Forest Habitats}

Mobbing behavior in birds is a well-known phenomenon, which occurs when a predator is detected and alarm calls are produced to alert others [21,22]. Lorenz (1963) [23] was the first to describe mobbing in his book On Aggression. Bird calls decrease the predator's success by confusing it and eventually driving it from the area [21]. Birds' vigilance behavior includes paying attention to the alarm calls of others [24], changing their feeding mode [25], and evading the predator if encountered [26]. Although mobbing calls may cause some species to be less vocal, so that they remain undetected when inspecting a potential threat [27], anti-predator behavior can rapidly spread within a bird community [28,29].

Species react selectively to other species' mobbing calls and their reactions to the alarm calls can vary between species [30-32] and seasons [27,33,34]. Furthermore, mobbing calls often attract mixed groups of species $[31,32,35]$ and can generate different behavior outcomes for different species. For example, some species will avoid or flee from the area of the alert calls and some will join the mobbing and participate $[27,35]$. Participation or exposure to mobbing calls also has a positive effect on the survival rate of juveniles and their chance of becoming a breeder [36].

\subsection{The Effect of Season on Mobbing Behavior}

Seasonality affects birds diversity in planted forests in the Mediterranean region, mainly because there are markedly differences of bird presence due to migration and wintering [1]. However, there is lack of information about the differences in reaction to mobbing between migrant, wintering, and all-year resident species. Previous studies examined bird responses to predators in the breeding season, but not between seasons, in various habitats such as alpine meadow [37], urban sites [38], and others (see reviews: [39,40]). Pettifor (1990) [41] did not find any difference in the response of common kestrels (Falco tinnunculus L.) to mobbing between seasons. No seasonality effect in responses to predator was also observed by Thys et al. (2019) [38] in a free-living great tits (Parus major L.) in the surroundings of Wilrijk, Belgium. Shedd $(1982,1983)[42,43]$ showed different responses across months of two active mobbing species in deciduous woodland, one migrating (American robin Turdus migratorius) and one local (black-capped chickadee Parus atricapillus L.). In the current study we examine the seasonality effect on birds' mobbing in planted pine forest.

\subsection{Inter and Intraspecific Responses to Mobbing}

Mobbing calls of one species may produce an interspecific reaction [44]. Lima (2009) [40] suggested that some of the individuals can benefits in fitness by reacting to interspecific mobbing. Indeed a few studies suggested a strong interspecific reaction to mobbing [30,45,46], while other species had a stronger responses to intraspecific mobbing [47-50]. Here we suggest that interspecific and intraspecific reactions are related to the mobbing caller species but also to the habitat structure.

The effects of vegetation structure on bird-mobbing behavior has been mainly studied in broad-leaved forests [31,51,52]. On the other hand, mobbing behavior in coniferous forest plantations has not been widely studied (but see [8,32]). Furthermore, only a few studies have applied their findings on behavioral ecology to conservation planning (but see [8]). Here we studied the patterns of mobbing activity in different types of conifer forest habitat in association with forest structure within managed, eastern Mediterranean pine forests. Specifically, we addressed the following questions: (1) What are the effects of different types of forest habitat and their vegetation characteristics on individual and community mobbing behaviors? (2) How does the season and bird status (all-year residents 
versus transients) affect mobbing behavior in different forest types? (3) How does the identity of the alarm caller affect the mobbing behaviors of intraspecific and interspecific species in the different forest types? To answer these questions, we performed a set of mobbing experiments in different seasons, in different types of pine forest habitats, and using different types of alarm calls. Based on the results of this study, we also make recommendations for pine forest management.

\section{Materials and Methods}

\subsection{Study Plots}

Our study was carried out within managed coniferous forests in northern Israel, from the Carmel ridge in the west to Ramot Menashe heights in the east. The climate is Mediterranean with an annual rainfall of $600-700 \mathrm{~mm}$ [53]. In Israel, about 98,000 ha ( $7 \%$ of the country) is managed forests, originally planned for timber or fuelwood [54,55]. All studied forest plots were over 47 years old and larger than 5 ha [55]. Two pine tree species are dominant in these forests: Aleppo or Jerusalem pine (Pinus halepensis Mill.) and Turkish pine (Pinus brutia Ten.).

The vegetation structure in the forest plots is complex. Tree density ranges from 150 trees per ha, with limited or an absence of shrubs, to an open forest with 50 trees per ha, with shrubby patches and gaps and mainly herbaceous vegetation [56]. The understory of the managed pine trees is highly variable between the study plots and comprises a mosaic of small trees, such as Quercus calliprinos and Pistacia palaestina, shrubs like Pistacia lentiscus L., Phillyrea latifolia L., Calicotome villosa (Poir.) Link, and Rhamnus lycioides L., and climbers, such as Smilax aspera L. and Clematis cirrhosa L. [57]. Study plots were chosen with a variety of tree densities and heights and understory compositions and were grouped into three types of forest habitat: (a) Dense pine forest (DF) with a diverse understory of shrubs and shrub-like trees $(n=8)$; (b) open pine forest (OF) with natural broadleaf trees and an understory of large shrubs $(n=7)$; and (c) dense pine forest with an absence of or almost no understory (NF) except herbaceous vegetation $(n=6)$.

\subsection{Bird Survey}

Bird surveys were conducted by fixed point counts [58], one point per study plot, with at least $250 \mathrm{~m}$ between the point counts to minimize the potential for individual birds to be counted at multiple points $[59,60]$. Each point count was located at least $50 \mathrm{~m}$ deep in the forest to avoid edge effect. We used a circular point-count method with a $50 \mathrm{~m}$ radius [59-61] to estimate bird density, species richness and diversity in each study plot $[18,60]$. All birds heard or seen from the census station over a 10-min interval $[59,61]$ were tracked and documented by species, date of detection, and distance to two radius bands: 0 to $50 \mathrm{~m}$ and $50 \mathrm{~m}$ to infinity (plot edge) from the observer [58]. Birds that were flushed from the plot when approaching the point-count station were recorded as present at the time of counting [61,62]. Birds crossing in flight over the station (up to $25 \mathrm{~m}$ ) during the census were also counted [63].

Each point-count station was visited 3 times in each season: fall (between late August to mid-October), winter (between late October to mid-March), spring (between late-March to early-June), and summer (between mid-June to mid-August) over a timespan of two years (2015-2017). Thus, we visited each point-count station 24 times during our research. Bird counts were carried out in fine weather between sunrise and noon during the spring, summer and fall; in the winter, counts occurred between 07:00 and 14:00. Point-count data was used to determine species richness [17] in the three types of forest habitats.

\subsection{Vegetation Structure in the Three Types of Forest Habitat}

Vegetation measurements were carried out by two transects in a $25 \mathrm{~m}$ radius around each point count and included the cover percentage of understory perennial species, herbaceous vegetation and exposed soil and rock surfaces $[57,62]$. Plant species were recorded every $10 \mathrm{~cm}$ along the transects and 
were categorized into life form, height level [57], and species. The cover percentage of each species and life form was categorized into four layers: ground (below $1 \mathrm{~m}$ ), shrub level (1 to $5 \mathrm{~m}$ ), low canopy (5 $\mathrm{m}$ up to canopy level), and treetop level [19,62]. Percentages were calculated independently for each life form such that the total cover percentage could reach more than $100 \%[57,64]$. The following parameters were measured for pine trees: average percentage of canopy cover, treetop height, tree diameter at breast height, and tree density $[57,65]$. The vegetation survey was carried out during spring 2017 in all plots.

\subsection{Estimated Response Level to Mobbing Calls}

Playbacks of mobbing calls can significantly increase the probability of visual observations of birds in coniferous forests $[27,66]$. Mobbing calls are an efficient tool for studies of birds' ecological behavior $[46,66]$. We estimated vigilance using mobbing experiments at the same 21 fixed point counts. Vigilance levels were measured using recorded calls made by Roché (1993) [67-69] of two common all-year resident species (Parus major L. and Sylvia melanocephala Gmelin) as well as of the non-visiting species Periparus ater L., which is very common in Europe and has an overlapping distribution with many of the transient and winter-resident bird species in our study area [70]. The calling sounds were played using a portable speaker, located $1 \mathrm{~m}$ away from a tree and $1.5 \mathrm{~m}$ up from the ground in a Pistacia lentiscus shrub. The speaker was viewed from a distance using binoculars in $10 \mathrm{~min}$ intervals [71,72]. Mobbing experiments included a 10 min playback of each bird species with 15 min break between each playback. The order of the three playbacks was random. The playback experiments were repeated eight times in each plot during 2016 and 2017: two in the fall (September to November), two in the winter (December to March), and four in the breeding season (April to July).

We recorded responses by the mobbing behavior in $50 \mathrm{~m}$ radius from the speaker of each individual with two parameters: distance and time. The distance from the speaker was recorded [52,72] as the response level [73]. We also noted the time of reaction of the first responder [49] because first responders to mobbing subject to greater risk from the predator, since they start to react before mobbing behavior is spread across the surrounding bird community $[28,29]$. We then followed the appearance of other birds to the mobbing event for $10 \mathrm{~min}$ and identified individual bird's mobbing reaction times and distance from the speaker [52]. We also recorded mobbing reactions at the bird community level by counting the number of birds and the number of species that responded in each mobbing event (bird abundance and bird richness, respectively, hereafter). Finally, we also compared the inventory of species that responded in mobbing experiments to the inventory of species that we observed in bird surveys within the same plots.

\subsection{Statistical Analysis}

The combined effect of habitat type, season, and mobbing type (fixed factors) on the number of responding birds were analyzed using the linear mixed model. We used the linear mixed model to examine the species richness of responders to the playback of each caller species in each season using lme4 $\mathrm{R}$ package [74]. Means of distance, time of response, bird abundance, and species richness per trial in three different types of forest habitat using three types of mobbing were compared by ANOVA and Bonferroni test [75]. ANOVA was also used to compare birds' reaction time in three types of forest habitats to three types of mobbing call. These analyses were performed by SPSS 21 [76]. Chi-square test was used to examine inter- and intraspecific species differences, and a binomial test was conducted to compare the numbers of resident and transient birds responding to calls in each habitat. The linear model for the number of responding birds to mobbing calls with respect to various parameters of forest vegetation structure was also calculated with the lme4 R package [74]. $p$-values less than 0.05 were considered significant for all tests. 


\section{Results}

\subsection{Responders to Mobbing Calls in Each Forest Type Habitat}

A total of 689 birds of 17 species responded to the played mobbing calls, representing $52 \%$ of a total 33 species observed in the surveys of the same plots and seasons. A significantly higher proportion of species responded to the mobbing calls in the two forest habitats with developed understory, 53\% in the OF and $70 \%$ in the DF, whereas only 31\% responded in the forest without understory (NF; pooled across seasons and caller species; Figure 1). The percentage of species that responded to calls in each season also differed (pooled across habitat types and caller species). Only $41 \%$ and $45 \%$ of the species reacted to calls in the fall and breeding season (spring-summer), respectively. On the other hand, $95 \%$ of the species which were observed in the winter responded to calls. Responses by bird status also varied: $67 \%$ of all-year resident species which were observed reacted to the calls $(50 \%$ in the fall, $70 \%$ in the winter, and $53 \%$ in the breeding season), whereas only $47 \%$ of transient species which were observed reacted ( $38 \%$ in the fall, $75 \%$ in the winter, and $31 \%$ in the breeding season).

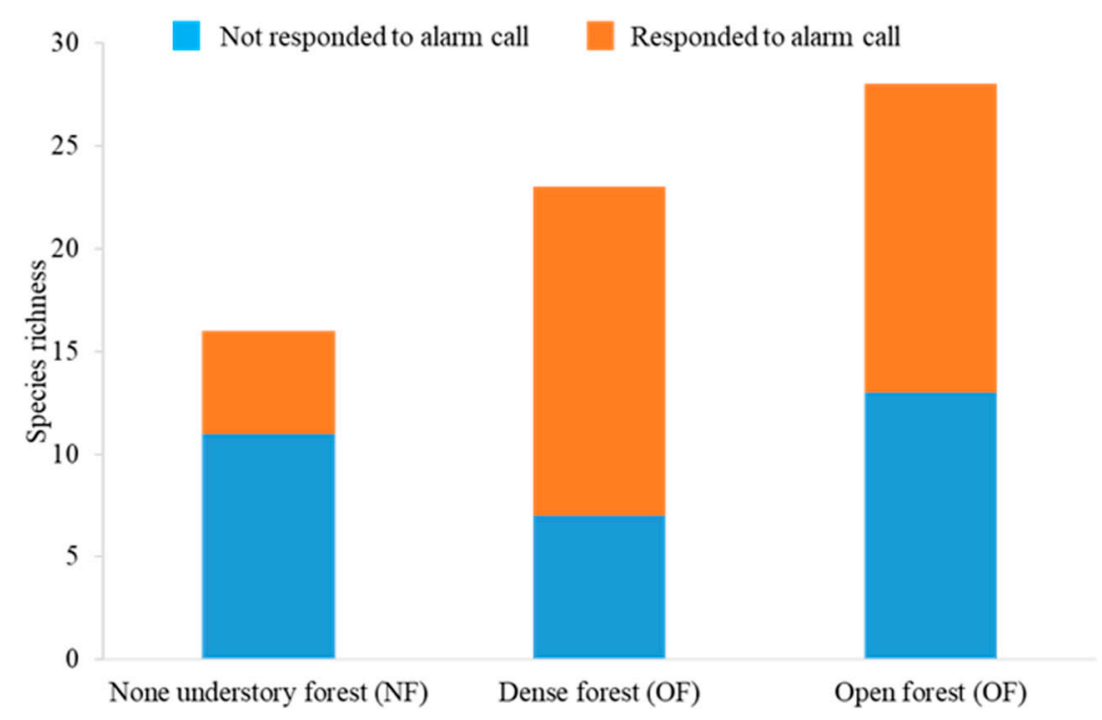

Figure 1. The total number of species that responded to alarm calls (orange) and number of species that were observed in the survey but did not respond to alarm calls (blue) in three types of pine forest habitats (pooled across all seasons and caller species). Significant differences between the observed and expected number of responders versus not responders were detected in NF (Chi-square $=31.6$, $d f=1, p<0.01), \mathrm{DF}($ Chi-square $=484.1, d f=1, p<0.001)$, and OF habitat (Chi-square $=149.5, d f=1$, $p<0.001)$.

\subsection{The Effect of Habitat, Season, and Caller Species on the Responding Bird Community}

\subsubsection{The Effect on Bird Abundance}

The number of birds that responded to alarm calls during the $10 \mathrm{~min}$ trials was significantly affected by habitat type $(F=13.813, d f=2,17, p<0.001$, pooled across seasons and caller species), season ( $F=21.239, d f=2,16, p<0.001$, pooled across habitat types and caller species), and caller species ( $F=27.480, d f=2,16, p<0.001$, pooled across habitat types and seasons) (Table S1). Furthermore, there were significant interaction effects on the number of responding birds of season and habitat type $(F=4.084, d f=4,34, p=0.01)$, caller species, and habitat type $(F=3.556, d f=4,34, p=0.02)$, as well as season and caller species $(F=4.211, d f=4,14, p=0.01)$. The effect of the triple interaction of habitat, season, and caller species on the number of responding birds was not significant $(F=1.600, d f=8,28$, $p=0.17)$ (Table S1). 
There were significantly fewer responders in the forest with no understory (NF) compared to dense (DF) and open (OF) pine forests (Figure 2). The number of responding birds to the calls of $S$. melanocephala was significantly higher than for P. ater in DF and OF habitats (Figure 2). No significant differences were detected in the total number of responding birds to calls of $P$. major in comparison to both S. melanocephala and P. ater (Figure 2).

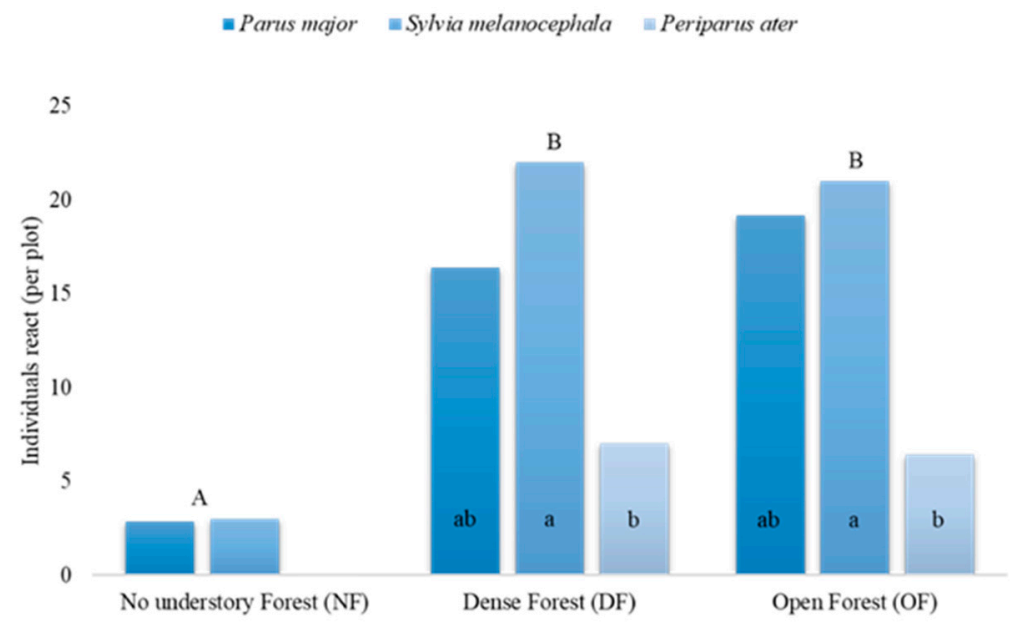

Figure 2. Total number of birds (pooled across all species) responding to alarm calls of three bird species ( $F=9.41, d f=2,106, \mathrm{p}<0.001$, pooled across seasons) in three types of pine forest habitat $(F=6.61, d f=2,106, p<0.001$, pooled across seasons). Capital letters above bars represent significant $(p<0.05)$ difference between the three forest types. Small letters within bars indicate significant $(p<0.05)$ differences between three caller species within habitat types (Bonferroni multiple comparisons).

The number of responding birds to calls of each caller species ( $F=14.28, d f=2,108, p<0.001$, pooled across all habitats, Figure 3) was higher in the winter than in the two other seasons (Figure 3). In the winter, mobbing calls of P. major attracted the highest number of responders (Figure 3). However, in the breeding season, the greatest number of birds responded to the calls of $S$. melanocephala. Reactions to the calls of $P$. ater in each season was significantly less pronounced than for the two other caller species (Figure 3).

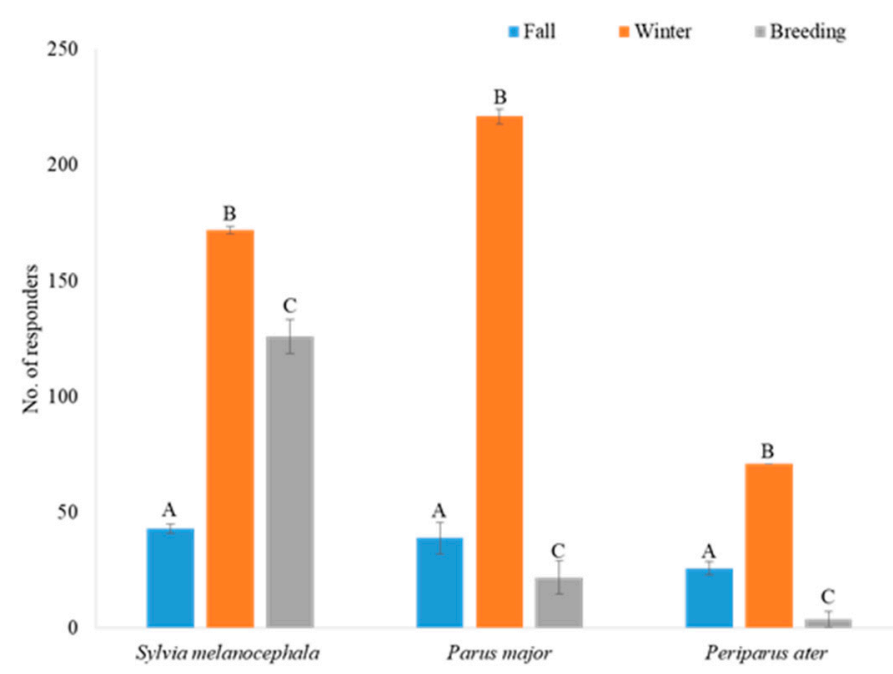

Figure 3. Number of individuals $\pm \mathrm{SD}$ (pooled across all habitats) that responded to each mobbing caller type in each season. Letters above bars indicate significant $(p<0.05)$ difference between seasons within each bird species (Bonferroni multiple comparisons). 
The mobbing reaction level, as expressed by the total number of individuals accumulated around the speaker over time, was different between seasons and habitats and caller species. For example, in the winter, the accumulated number of responding species to $S$. melanocephala calls was highest in the OF then both the NF and DF habitat $(F=5.75, d f=2,39, p=0.006)$. On the other hand, when P. major calls were played, the highest number of responding birds occurred in the DF habitat $(F=5.14, d f=2$, $49, p=0.009$ ) (Figure 4). In addition, the reaction level to $S$. melanocephala calls in the winter was higher in the OF comparing to the DF habitat but not as high as the DF in the breeding season $(F=6.45, d f=2$, $54, p=0.003$ ) (Figure 4).

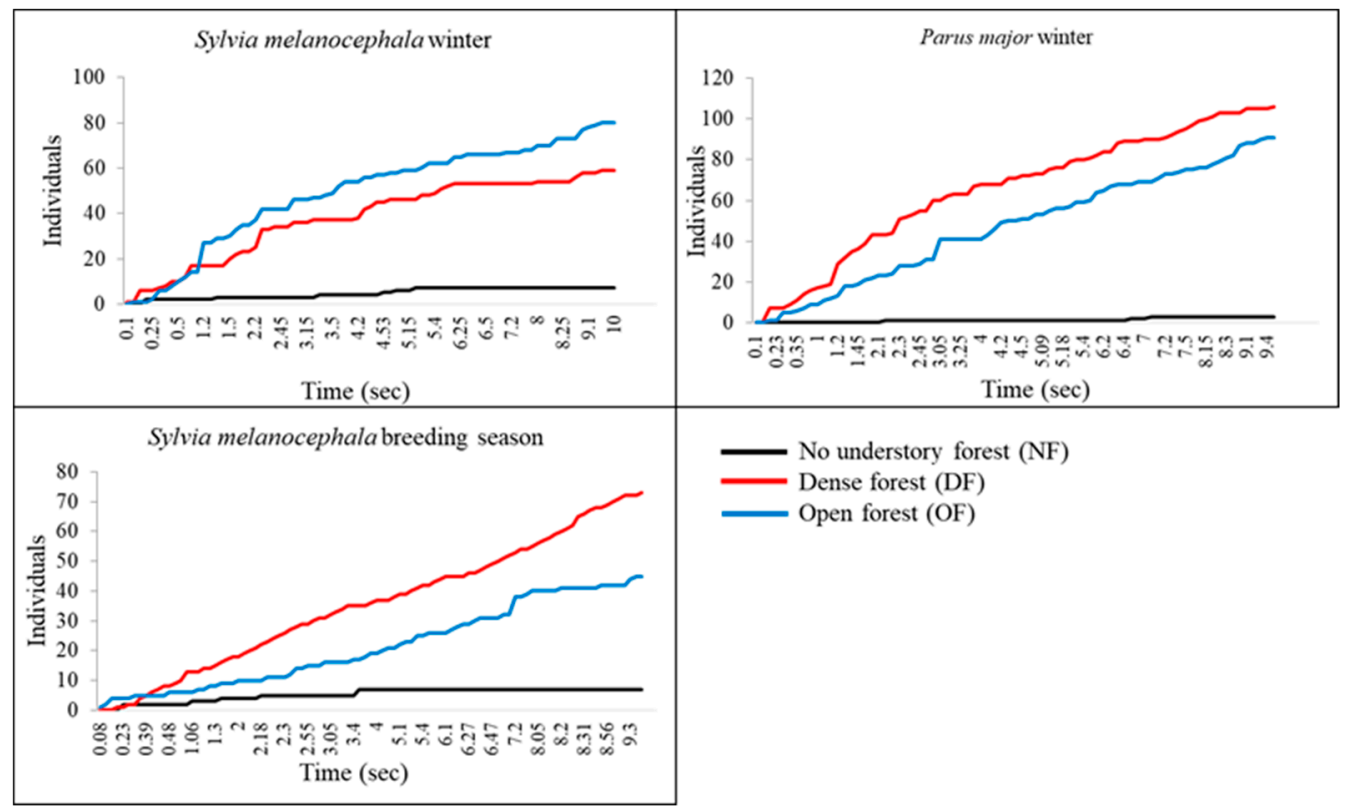

Figure 4. The accumulated number of responders throughout the experiment (the reaction level) with respect to different mobbing callers, forest habitats, and seasons.

We used a mixed model analysis to detect the role of various parameters in forest structure and caller species on the number of responding birds. The significant model $(F=2.558, d f=18,92, p<0.001$, $R^{2}=33 \%$, Table 1) demonstrates that, among examined vegetation parameters, only shrub cover was found to be significant, with a positive effect on the number of responders (Table 1). The effects of tree density and tree height on the number of responding birds was not significant (Table 1).

Table 1. Linear model for the number of responding birds to mobbing calls with respect to various parameters of forest vegetation structure.

\begin{tabular}{ccccc}
\hline $\boldsymbol{F}_{\mathbf{1 8}, \mathbf{9 2}}=\mathbf{2 . 5 6}$ & $\boldsymbol{R}^{\mathbf{2}}=\mathbf{0 . 3 3}$ & \multicolumn{2}{c}{$p<\mathbf{0 . 0 0 1}$} \\
\hline & Estimate & Std. Error & $\boldsymbol{t}$ Value & $\operatorname{Pr}(>|\mathbf{t}|)$ \\
\hline Intercept) & -54.1 & 37.9 & -1.426 & 0.16 \\
\hline Shrub cover $(\mathrm{m})$ & 0.0017 & 0.0005 & 3.184 & $<0.001$ \\
\hline Trees per ha & 0.0528 & 0.0334 & 1.581 & 0.12 \\
\hline Ground cover $(\mathrm{m})$ & 0.027 & 0.040 & 0.675 & 0.50 \\
\hline Tree height $(\mathrm{m})$ & 2.51 & 2.04 & 1.228 & 0.22 \\
\hline Low tree cover $(\mathrm{m})$ & 0.44 & 0.24 & 1.864 & 0.07 \\
\hline P. major mobbing & 4.75 & 1.37 & 3.468 & $<0.001$ \\
\hline $\begin{array}{c}\text { S. melanocephala } \\
\text { mobbing }\end{array}$ & 3.35 & 1.27 & 2.625 & 0.01 \\
\hline
\end{tabular}




\subsubsection{The Effect on Species Richness}

Pooling the data across seasons and the type of alarm caller, the species richness of responding birds was significantly affected by the type of forest habitat $(F=21.584, d f=2,17, p<0.001$, pooled across seasons and caller specials), season $(F=34.602, d f=2,16, p<0.001$, pooled across seasons and types of alarm caller), and caller species $(F=25.647, d f=2,16, p=0.003$, pooled across seasons and types of alarm caller) (Table S2). The species richness of responders was also significantly affected by the interaction effects of season and habitat type $(F=4.955, d f=4,32, p=0.003)$ and caller species $(F=7.158, d f=4,14, p=0.002)$. By contrast, the interaction effect of caller species and habitat type was not significant $(F=1.094, d f=4,28, p=0.37)$ (Table S2).

The species richness of responding birds to the mobbing calls of $S$. melanocephala (pooled across habitat types and seasons) was much higher than to the calls of P. major and P. ater (Figure 5). In the breeding season, the greatest species richness of responders was to calls of $S$. melanocephala. However, in the winter, the mobbing calls of $P$. ater attracted the highest number of species (Figure 5).

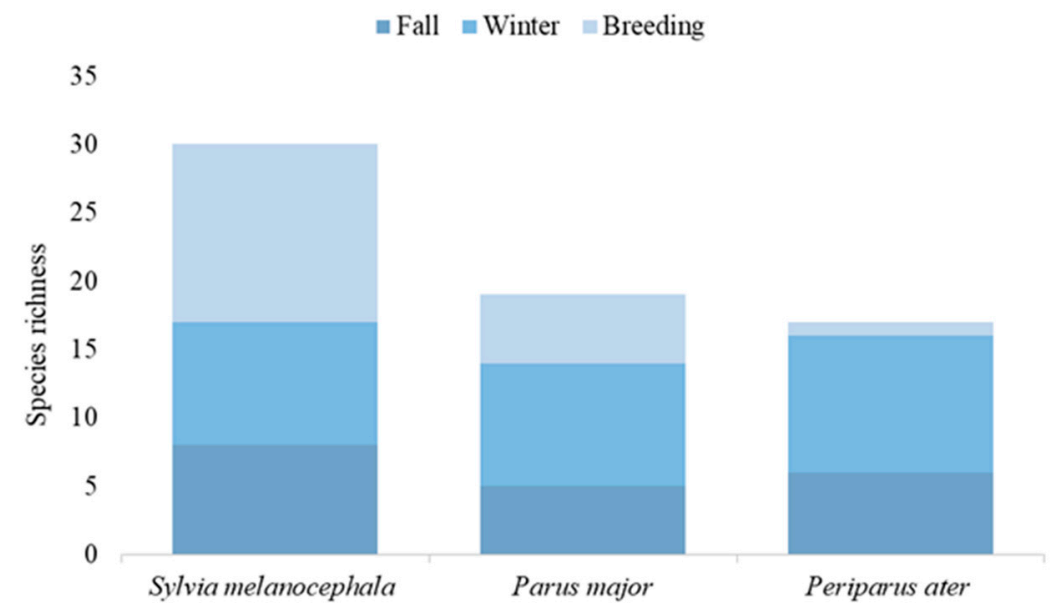

Figure 5. Species richness of responders to the playback of each caller species in each season (pooled across all habitats). Species richness was significantly affected by the interaction of season and the caller species (mixed linear model, $F=7.158, d f=4,14, p=0.002$ ).

\subsection{The Effect of Habitat, Season, and Caller Species on the Individual Level of Response}

We compared the level of response (distance from the speaker and time elapsed between the first mobbing call and the appearance of the first bird) across habitats, seasons, and caller species using $\log$ transformation of the distance. There was no significant effect of the type of forest habitat on the average distance from the responder to the player $(F=1.018, d f=1,10, p=0.33)$ but the interaction effect of habitat and caller species was significant $(F=21.847, d f=2,20, p<0.001)$ (Table S3). There was a significant effect of caller species on the average distance from the responder to the mobbing player in the DF $(F=3.380, d f=2,52, p=0.04)$; in particular, the average distance that individuals approached the speaker playing the $P$. major call was much closer than when calls were played of the other two caller species (Figure 6). A similar pattern of response behavior, although not significant, was also found in the $\mathrm{OF}(F=2.760, d f=2,38, p=0.08)$ and NF $(F=0.110, d f=1,9, p=0.10)$ habitats. The responders to the playback calls of $P$. ater kept a greater distance from the speaker than to the playback calls of other caller species in both the DF and OF (no responses to this caller were observed in the NF habitat).

The time elapsed between the call and response of the first bird was not significantly affected by either habitat $(F=0.777, d f=1,10, p=0.39)$, caller species $(F=0.685, d f=2,9, p=0.529)$, or their interaction $(F=0.918, d f=2,9, p=0.68)$. However, the accumulated number of responding birds over the $10 \mathrm{~min}$ trial varied between habitats, seasons and caller species. In the winter, S. melanocephala calls attracted more responders than P. major over time in the OF habitat $(F=5.750, d f=2,39, p=0.006)$, 
whereas P. major calls attracted higher responses than S. melanocephala in the DF habitat $(F=5.140$, $d f=2,49, p=0.009$ ). In the breeding season, the number of responses to the $S$. melanocephala playback was higher in the DF habitat than the other two forest types $(F=6.450, d f=2,54, p=0.003)$.

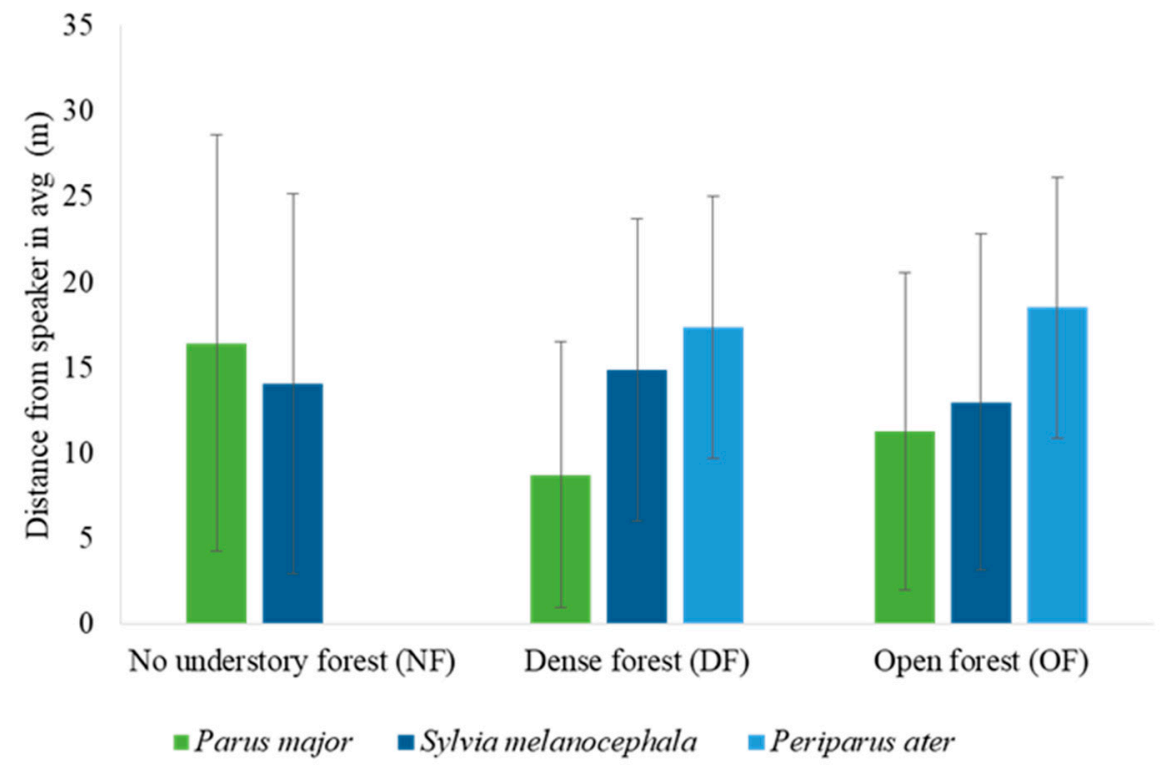

Figure 6. Distance from speaker (mean $\pm \mathrm{SD}$ ) of individual responders to the playbacks of three different caller species in three forest habitats (pooled across seasons).

\subsection{Intra- versus Interspecific Responses}

The comparison between intra- and interspecific responders was carried out in the winter, the season with the highest number of responding birds. P. major calls attracted a significantly higher number of intraspecific birds than expected at random but a lower number of interspecific than expected (Chi-square $=4.18, d f=1, p=0.04$ ). S. melanocephala showed the opposite pattern: Its calls attracted a lower number of intraspecific birds than expected at random but a higher number of interspecific than expected (Chi-square $=3.15, d f=1, p=0.007$, Figure 7).

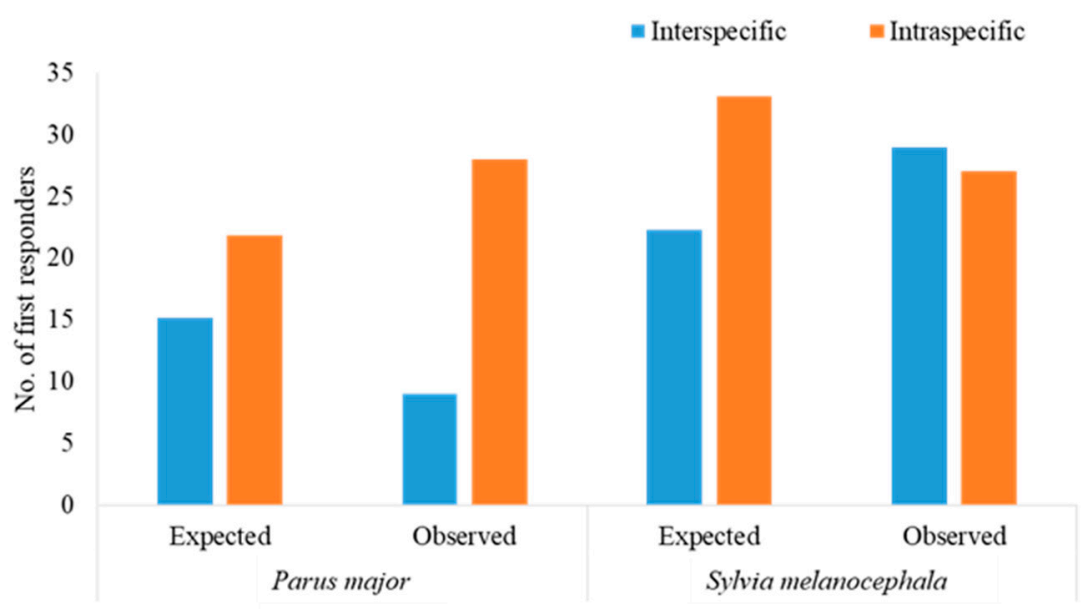

Figure 7. Total number of intra- and interspecific first responders to the playback calls of great tit (Parus major) and Sardinian warbler (Sylvia melanocephala) (pooled across habitats and seasons). Significant differences between the observed and expected number of intra- and interspecific first responders to the mobbing playbacks were detected for both species (see text). 


\subsection{The Responses of Wintering versus All-Year Residents}

$P$. ater calls in the winter (pooled across habitats) attracted five non-resident wintering species and five all-year resident species, whereas $S$. melanocephala calls attracted six wintering species and three resident species and P. major calls attracted five wintering species and four resident species (Figure 8). Pooling across the three caller species, four wintering species responded more than expected at random in the DF and only the common chiffchaff (Phylloscopus collybita Vieillot) responded less. In the OF habitat, five species responded more than expected at random (Table S4).

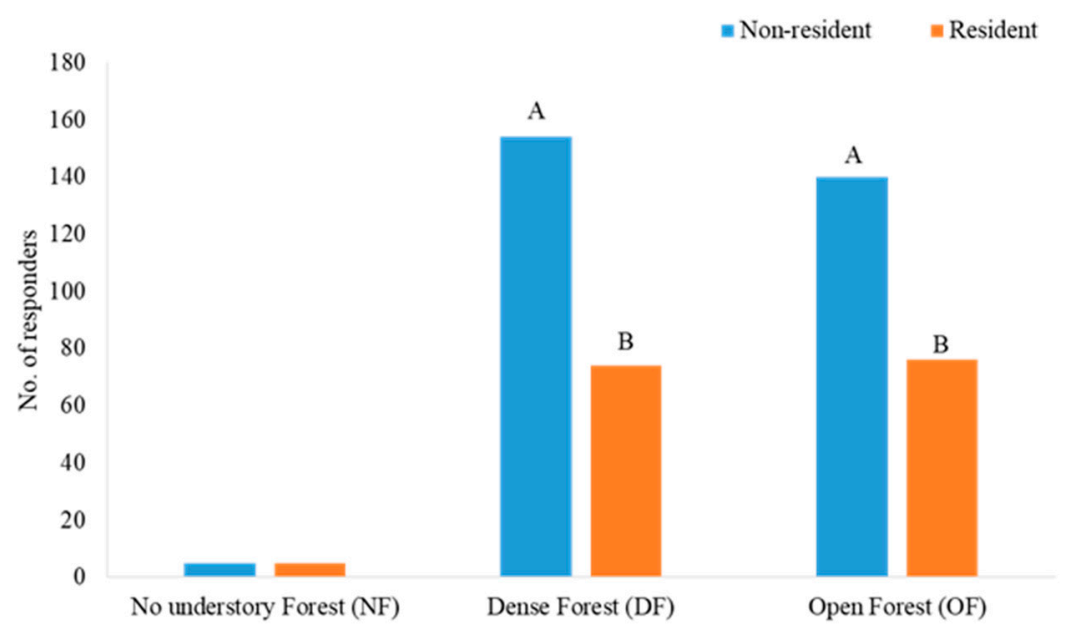

Figure 8. Number of individuals (pooled across responding species) responding to mobbing calls (pooled across caller species) in NF, DF, and OF forest habitats in the winter. Different capital letters above bars indicate significant differences between the number of responding all-year resident and wintering species in each forest type using binomial test $(p<0.05)$.

Significantly more non-resident wintering birds responded to mobbing calls than all-year residents in the DF (68\%) and OF habitats (63\%), but not in the NF (50\%) (pooled across caller species; Figure 8). Two wintering species, common chaffinch (Fringilla coelebs L.) and European robin (Erithacus rubecula L.), were observed more than expected relative to their abundance in the DF and OF habitats (Table S4). The wintering species Phylloscopus collybita and all-year resident $S$. melanocephala were observed less than expected in the DF habitat but more than expected in the OF habitat (Table S4). P. major was observed only by four individuals more than expected in the DF habitat; however, it was observed two times more than expected in the OF habitat (Table S4). Three species that responded to mobbing calls were not observed in the survey: Blackcap (Sylvia atricapilla L.), lesser whitethroat (Sylvia curruca L.) and Upcher's warbler (Hippolais languida Hemprich \& Ehrenberg).

\section{Discussion}

\subsection{The Effect of Forest Structure on Mobbing Behavior}

Mobbing behavior at both the community and individual levels is governed by the structure of the pine forest. Previous studies demonstrated that the composition of a bird community is determined by the stage of forest growth and the understory characteristics that affect the aural, visual and physical environments $[4,5]$. Indeed, habitat structure is well known as an important element in mobbing responses in woodlands and forest $[2,52,77]$. In our study, the pine forest with no understory (NF) attracted a lower number of responding individuals and species than the two forests with understory (DF and OF). Furthermore, the responding birds in the NF, comparing to the DF and OF, kept a greater distance from the speaker playing P. major calls and did not respond at all to the calls of $P$. ater. However, both the DF and OF habitats attracted a higher number of responders than the NF habitat and thus responders in the DF and OF presented a higher risk behavior than in the NF. 
Some non-exclusive explanations for this phenomenon including: a) A much poorer bird community inhabited the forest with no understory. Indeed, we demonstrated that the NF habitat supported lower species richness, lower bird abundance, and a much simpler social network [1]. b) The birds in this forest without understory have few hiding locations, such that approaching the speaker increases their risk to predation. This explanation is supported by previous studies that showed that shrubs are common escape cover for tropical forest birds [31]. Furthermore, we found that shrub cover was the most important parameter of the vegetation structure of our three types of pine forests that governs the mobbing reaction. Other studies demonstrated that the response of birds to mobbing calls was influenced by forest structure [3], with a positive correlation to tree density and height [34,78]. In our study, the response to mobbing calls was not significantly affected by tree density and height. Thus, in our pine forests, the effect of the shrub layer was stronger than that of tree attributes.

The mobbing calls in the two forest habitats with understory attracted a similar number of birds and species. However, the number of birds that were attracted in the winter to P. major calls in the dense forest (DF) was higher than in the open forest (OF). On the other hand, when S. melanocephala calls were played in the winter, we detected the opposite pattern, with more birds responding in the OF than the DF. S. melanocephala is more abundant in the winter than P. major in the study sites: Five times more in the DF and greater than three times more in the OF [1]. Therefore, the difference in the responses to the two species' playback calls between the DF and OF habitats was unrelated to their abundance in these two habitats. However, these different behavioral patterns may emerge due to differences in the dynamic territorial selection and foraging behavior of each species between the two forest types [70,79]. The main implication for conservation and forest management that emerges from our study is to encourage well-established understory vegetation in the conifer forest, with special attention to the shrub layer to support a more diverse and active bird community

\subsection{The Effect of Season on Mobbing Behavior}

Previous studies largely overlooked the differentiation in mobbing behavior across different seasons (but see $[41,42,80]$ ). We found that the number of responding species to mobbing calls was significantly different among seasons; in the winter, the number of responders was higher than expected for several wintering species, irrespective of caller species. A low response to mobbing by local birds in the non-breeding season compared to the breeding season was shown in deciduous woodland [42] and mountain landscapes [80]. The relatively few mobbing reactions during the breeding season can be explained by the low-risk behavior of nesting species in order to reduce predation [81]. Other studies demonstrated that many species do respond to mobbing calls during the breeding season in tropical forests [52] as well as in coniferous and mixed forest [27,47,82]. However, these studies did not compare mobbing behavior across seasons.

The playback calls of $P$. major during the breeding season generated an extremely low response in all types of forest habitats compared to the intensive response to calls of $S$. melanocephala. Lind et al. (2005) [33] demonstrated differences in the anti-predator behavior of $P$. major to a visible predator as opposed to only the auditory alarm of other $P$. major, finding that the response to a visible predator was significantly higher than to alarm calls. Therefore, it is possible that the limited response to the calls of P. major during the breeding season in our study were due to the lack of a visible predator on site. Yet, it is well documented that there is a variety of responses among bird species to different types of alarm calls [48]. Accordingly, it is still puzzling why birds avoid the P. major calls during the breeding season.

The playbacks of mobbing calls in the winter generated a high response in all three types of pine forests, even after normalizing the numbers of responding birds to their abundance in the point-count survey. High responses to mobbing in the winter may originate from the presence of heterospecific flocks that generate anti-predator behavior [83], which generates high-risk behavior according to the safety-in-numbers hypothesis [84]. High mobbing responses, specifically in the fall and winter months, were also observed at deciduous woodland [42]. 
We observed moderate mobbing behavior in the fall. However, other studies pointed out that the number of responders in the fall may rise due to the influx of migrating birds that join mobbing against predators in open fields [41]. However, most of the responders in our fall trials were resident species. Furthermore, vigilant behavior in the fall by parents of young fledglings and the fledglings themselves was observed in deserted agriculture fields [85] and in mixed forest [86].

\subsection{Inter-versus Intraspecific Responses}

It is expected that different species generate different responses to mobbing calls [28]. For example, F. coelebs, one of the common wintering responders at our study sites, also showed an interspecific response to alarm calls by Greenfinch (Chloris chloris L.) [45]. Still, it is expected that an individual will respond more strongly to its own species [48]. Indeed, in our study, the S. melanocephala playback attracted intraspecific responders, whereas $P$. major attracted much more interspecific than intraspecific responders. Although $S$. melanocephala was the most abundant species in our study sites [1], it was not the first to respond to any of the three types of caller species. Hence, abundance does not necessarily correlate with mobbing behavior [84].

Previous studies demonstrated that the American black-capped chickadee (Parus atricapillus) attract their kind more than others $[30,46]$. However, other studies in forests showed that mobbing calls attracted interspecific responders [47] and provoked an interspecific reaction [28,48-50], as was the case with $P$. major in this study. Therefore, this study suggests that interspecific responses to the cue of mobbing varies between P. major and S. melanocephala, and more study is needed to explore this variation between species.

\subsection{Local versus Non-Resident Responses}

A high response to mobbing was recorded both for local species, such as Turdus migratorius L. [43] and P. major [33,87], and for migratory species, such as F. coelebs [82]. In our study, more non-resident than all-year resident birds responded to mobbing playback in winter. Still, Gehlbach and Leverett (1995) [88] found that in deciduous forests, resident species were more responsive than non-resident species in richness and numbers throughout the year. Non-resident wintering species, such as E. rubecula, demonstrated a significantly higher level of response than expected relative to their presence in these pine forests. Many wintering birds establish temporary territories [89-91], E. rubecula, among them [92]. Nocera et al. (2008) [93] suggested that such an intensive reaction by non-residents is due to their low familiarity with local predators. However, the response to mobbing calls varied among forest habitats both in wintering and all-year resident birds.

The response to the mobbing calls of $P$. ater, the species that does not occur in our pine forests, was not as intensive as to the calls of the two all-year resident birds. Furthermore, the responding birds kept a greater distance from the speaker than they did for the calls of the two all-year residents. These results support the possibility that interspecific responses are genetically coded behavior [50] or conspecific identification [72], along with allopatric response to mobbing calls [48,94]. Yet, most of the responders to $P$. ater calls were non-resident species. The distribution of some of these responders in Europe, such as E. rubecula, F. coelebs, S. atricapilla, and P. collybita, overlaps with the distribution of P. ater [70]. Thus, these responders may be reacting to familiar alert calls in their wintering areas [50].

\subsection{Using Mobbing Calls in Forest Habitats}

In the winter, $95 \%$ of the species that were recorded in the survey also responded in the mobbing experiments, suggesting that this method, of mobbing playback, is effective in these pine forests. Moreover, three species responded to mobbing calls that were not recorded in the survey, probably as a result of low probabilities of detection and less vocalization during winter [27], or rareness [46]. Conducting mobbing experiments combined with point-count surveys seems to be efficient $[27,46]$ and can create more profundity to our understanding of birds' habitat choices. 


\section{Conclusions}

The study of forest management through the ecology of birds is a well-developed field [95]. But the set of available practical tools is mainly based on traditional ecological studies, even though new technologies, such as GIS (Geographic Information System) and remote sensing, are available [96,97]. We demonstrated the ability to combine a bird survey with behavioral study of birds to address research questions on forest ecology and management. Such combination seems to be an important methodology that has been largely overlooked. We conclude that a robust understory supports a rich and active bird community. Moreover, we found that transient bird species have a significance effect on bird community mobbing behavior, even with alarm calls produced by resident species.

Supplementary Materials: The following are available online at http://www.mdpi.com/1999-4907/10/9/762/s1, Table S1. Mixed-model table of abundance during mobbing trials and the influence of habitat, season, and caller species. Table S2. Mixed-model table of species richness during mobbing trials and the influence of habitat, season, and caller species. Table S3. Mixed model of distance of the responding birds from the speaker during mobbing trials and the influence of caller species and habitat in the dense forest (DF) and in the open forest (OF). Table S4. Differences between observed and expected numbers of responding birds to mobbing calls in the winter in the dense forest (DF) and in the open forest (OF).

Author Contributions: U.D. and I.I. designed the study. U.D. collected all the data. U.D. and I.I. analyzed the data and wrote the manuscript together. Both authors read and approved the final manuscript.

Funding: This study was supported by a grant from the Jewish National Fund (KKL, grant No. 60-05-095-14).

Conflicts of Interest: The authors declare no conflicts of interest.

\section{References}

1. Dagan, U.; Izhaki, I. Understory vegetation in planted pine forests governs bird community composition and diversity in the eastern Mediterranean region. For. Ecosyst. 2019, 6, 29. [CrossRef]

2. Villard, M.-A.; Trzcinski, M.K.; Merriam, G. Fragmentation effects on forest birds: Relative influence of woodland cover and configuration on landscape occupancy. Biology 1999, 13, 774-783. [CrossRef]

3. Hannon, S. Effect of stand vs. landscape level forest structure on species abundance. Landscape 2005, 51. [CrossRef]

4. Schieck, J. Biased detection of bird vocalizations affects comparisons of bird abundance among forested habitats. Condor 1997, 99, 179-190. [CrossRef]

5. Whelan, C.J.; Maina, G.G. Effects of season, understorey vegetation density, habitat edge and tree diameter on patch-use by bark-foraging birds. Funct. Ecol. 2005, 19, 529-536. [CrossRef]

6. Izhaki, I. Passerine bird communities in Mediterranean pine forests. In Ecology, Biogeography and Management of Pinus hiaepensis and P. brutia Forest Ecosystems in the Mediterranean Basin; Ne'eman, G., Trabaud, L., Eds.; Backhuys Publisher: Leiden, The Netherlands, 2000; pp. 237-250.

7. Gil-Tena, A.; Saura, S.; Brotons, L. Effects of forest composition and structure on bird species richness in a Mediterranean context: Implications for forest ecosystem management. For. Ecol. Manag. 2007, 242, 470-476. [CrossRef]

8. Smith, K.M.; Keeton, W.S.; Donovan, T.M.; Mitchell, B. Stand-level forest structure and avian habitat: Scale dependencies in predicting occurrence in a heterogeneous forest. For. Sci. 2008, 54, 36-46.

9. Batary, P.; Scherber, C.; Fronczek, S.; Normann, C.; Tscharntke, T. How do edge effect and tree species diversity change bird diversity and avian nest survival in Germany's largest deciduous forest? For. Ecol. Manag. 2014, 319, 44-50. [CrossRef]

10. Díaz, L. Influences of forest type and forest structure on bird communities in oak and pine woodlands in Spain. For. Ecol. Manag. 2006, 223, 54-65. [CrossRef]

11. Moning, C.; Müller, J. Critical forest age thresholds for the diversity of lichens, molluscs and birds in beech (Fagus sylvatica L.) dominated forests. Ecol. Indic. 2009, 9, 922-932. [CrossRef]

12. Diaz, M.; Carbonell, R.; Santos, T.; Telleria, J. Breeding bird communities in pine plantations of the Spanish plateaux: Biogeography, landscape and vegetation effects. J. Appl. Ecol. 1998, 35, 562-574. [CrossRef] 
13. Ross, B.D.; Morrison, M.L.; Hoffman, W.; Fredericksen, T.S.; Sawicki, R.J.; Ross, E.; Lester, M.B.; Beyer, J.; Johnson, B.N. Bird relationships to habitat characteristics created by timber harvesting in Pennsylvania. J. Pa. Acad. Sci. 2001, 74, 71-84.

14. Rey-Benayas, J.M.; Galván, I.; Carrascal, L.M. Differential effects of vegetation restoration in Mediterranean abandoned cropland by secondary succession and pine plantations on bird assemblages. For. Ecol. Manag. 2010, 260, 87-95. [CrossRef]

15. Robbins, C.S. Effect of forest fragmentation on breeding bird populations in the Piedmont of the mid-Atlantic region. In Proceedings of the 1979 Mid-Atlantic Natural History Symposium: Bird Populations-A Litmus Test of the Environment; Lynch, J.F., Ed.; Patuxent Wildlife Research Center: Laurel, MD, USA, 1980; pp. 31-36. Available online: https://pubs.er.usgs.gov/publication/5210240 (accessed on 30 August 2019).

16. Lynch, J.F.; Whigham, D.F. Effects of forest fragmentation on breeding bird communities in Maryland, USA. Biol. Conserv. 1984, 28, 287-324. [CrossRef]

17. Patterson, I.J.; Ollason, J.G.; Doyle, P. Bird populations in upland spruce plantations in northern Britain. For. Ecol. Manag. 1995, 79, 107-131. [CrossRef]

18. Sweeney, O.; Wilson, M.; Irwin, S. woodlands and plantation for breeding birds of native nests in Ireland. Irish Birds 2011, 9, 181-196.

19. Fuller, R.J. Bird Life of Woodland and Forest; Cambridge University Press: Cambridge, UK, 2003; ISBN 0521543479.

20. Robinson, S.K.; Holmes, R.T. Effects of plant species and foliage structure on the foraging behavior of forest birds. Auk 1984, 101, 672-684. [CrossRef]

21. Curio, E.; Ernst, U.; Vieth, W. The adaptive significance of avian mobbing. Etology 1978, 48, $184-202$. [CrossRef]

22. Frankenberg, E. The Adaptive significance of avian mobbing. Etology 1981, 55, 97-118. [CrossRef]

23. Lorenz, K. On Aggression; Routledge Publishing: London, UK, 1963; ISBN 9780415283205.

24. Sullivan, K.A. Information Exploitation by Downy Woodpeckers in mixed-species flocks. Behaviour 1984, 91, 294-311. [CrossRef]

25. Newman, J.A.; Recer, G.M.; Zwicker, S.M.; Caraco, T. Effects of predation hazard on foraging constraints: Patch-use strategies in grey squirrels [Sciurus cardinensis]. Oikos 1988, 93-97. [CrossRef]

26. Brown, J.S. Vigilance, patch use and habitat selection: Foraging under predation risk. Evol. Ecol. Res. 1999, 1, 49-71.

27. Rae, L.F.; Whitaker, D.M.; Warkentin, I.G. Variable effect of playback of chickadee mobbing calls on detection probability of boreal forest birds. J. Field Ornithol. 2015, 86, 51-64. [CrossRef]

28. Wheatcroft, D.; Price, T.D. Learning and signal copying facilitate communication among bird species. Proc. Biol. Sci. 2013, 280, 20123070. [CrossRef] [PubMed]

29. Ibáñez-A'Lamo, J.D.; Magrath, R.D.; Oteyza, J.C.; Chalfoun, A.D.; Haff, T.M.; Schmidt, K.A.; Thomson, R.L.; Martin, T.E. Nest predation research: Recent findings and future perspectives. J. Ornithol. 2015, 156, $247-262$. [CrossRef]

30. Hurd, C.R. Interspecific attraction to the mobbing calls of black-capped chickadees (Parus atricapillus). Behav. Ecol. Sociobiol. 1996, 38, 287-292. [CrossRef]

31. Sieving, K.E.; Contreras, T.A.; Maute, K.L. Heterospecific facilitation of forest-boundary crossing by mobbing understory birds in North-Central Florida. Auk 2004, 121, 738-751. [CrossRef]

32. Dutour, M.; Lena, J.P.; Lengagne, T. Mobbing behaviour in a passerine community increases with prevalence in predator diet. Ibis 2017, 159, 324-330. [CrossRef]

33. Lind, J.; Jöngren, F.; Nilsson, J.; Schönberg Alm, D.; Strandmark Lind, A. Information, predation risk and foraging decisions during mobbing in Great Tits Parus major. Ornis Fenn. 2005, 82, 89-96.

34. Shimazaki, A.; Yamaura, Y.; Senzaki, M.; Yabuhara, Y.; Nakamura, F. Mobbing call experiment suggests the enhancement of forest bird movement by tree cover in urban landscapes across seasons. Avian Conserv. Ecol. 2017, 12, 16. [CrossRef]

35. Desrochers, A.; Bélisle, M.; Bourque, J. Do mobbing calls affect the perception of predation risk by forest birds? Anim. Behav. 2002, 64, 709-714. [CrossRef]

36. Griesser, M.; Suzuki, T.N. Naive Juveniles Are More Likely to Become Breeders after Witnessing Predator Mobbing. Am. Nat. 2017, 189, 58-66. [CrossRef] [PubMed] 
37. Barash, D.P. Evolutionary aspects of parental behavior: Distraction behavior of the alpine accentor. Wilson Bull. 1975, 367-373.

38. Thys, B.; Lambreghts, Y.; Pinxten, R.; Eens, M. Nest defence behavioural reaction norms: Testing life-history and parental investment theory predictions. R. Soc. Open Sci. 2019, 6, 182180. [CrossRef] [PubMed]

39. Montgomerie, R.D.; Weatherhead, P.J. Risks and rewards of nest defence by parent birds. Q. Rev. Biol. 1988, 63, 167-187. [CrossRef]

40. Lima, S.L. Predators and the breeding bird: Behavioral and reproductive flexibility under the risk of predation. Biol. Rev. 2009, 84, 485-513. [CrossRef] [PubMed]

41. Pettifor, R.A. The effects of avian mobbing on a potential predator, the European kestrel, Falco tinnunculus. Anim. Behav. 1990, 39, 821-827. [CrossRef]

42. Shedd, D.H. Seasonal variation in mobbing intensity in the Black-capped Chickadee. Wilson Bull. 1983, 95, 343-348.

43. Shedd, D.H. Seasonal variation and function of mobbing and related antipredator behaviors of the American Robin (Turdus migratorius). Auk 1982, 99, 342-346.

44. Forsman, J.T.; Monkkonen, M.; Inkeroinen, J.; Reunanen, P. Aggregate dispersion of birds after encountering a predator: Experimental evidence. J. Avian Biol. 1998, 29, 44. [CrossRef]

45. Marler, P. Specific distinctiveness in the communication signals of birds. Behaviour 1957, 11, 13-39. [CrossRef]

46. Turcotte, Y.; Desrochers, A. Playbacks of mobbing calls of Black-capped Chickadees help estimate the abundance of forest birds in winter. J. Field Ornithol. 2002, 73, 303-307. [CrossRef]

47. Forsman, J.T.; Mönkkönen, M. Responses by breeding birds to heterospecific song and mobbing call playbacks under varying predation risk. Anim. Behav. 2001, 62, 1067-1073. [CrossRef]

48. Johnson, F.R.; Mcnaughton, E.J.; Shelley, C.D.; Blumstein, D.T. Mechanisms of heterospecific recognition in avian mobbing calls. Aust. J. Zool. 2003, 51, 577-585. [CrossRef]

49. Nolen, M.T.; Lucas, J.R. Asymmetries in mobbing behaviour and correlated intensity during predator mobbing by nuthatches, chickadees and titmice. Anim. Behav. 2009, 77, 1137-1146. [CrossRef]

50. Suzuki, T.N. Referential calls coordinate multi-species mobbing in a forest bird community. J. Ethol. 2016, 34, 79-84. [CrossRef]

51. Morris, D.W.; Davidson, D.L. Optimally foraging mice match patch use with habitat differences in fitness. Ecology 2000, 81, 2061-2066. [CrossRef]

52. Hua, F.; Sieving, K.E. Understory avifauna exhibits altered mobbing behavior in tropical forest degraded by selective logging. Oecologia 2016, 182, 743-754. [CrossRef]

53. Goldreich, Y. The spatial distribution of annual rainfall in Israel-A review. Theor. Appl. Climatol. 1994, 50, 45-59. [CrossRef]

54. CBS-Statistical Abstract of Israel Forest, Planted Forest Area. Available online: http://www.cbs.gov.il/ reader/shnaton/templ_shnaton.html?num_tab=st19_07\&CYear=2014 (accessed on 26 August 2015).

55. JNF. JNF Forests Data to 2014. Available online: http://www.kkl.org.il/afforestation-and-environment/ afforestation/forest-data-2014/ (accessed on 26 August 2015).

56. Ne'eman, G.; Izhaki, I. The effect of stand age and microhabitat on soil seed banks in Mediterranean Aleppo pine forests after fire. Plant Ecol. 1999, 144, 115-125. [CrossRef]

57. Schiller, G.; Ne'eman, G.; Korol, L. Post-fire vegetation dynamics in a native Pinus halepensis Mill. forest on Mt. Carmel. Isr. J. Plant Sci. 1997, 45, 297-308. [CrossRef]

58. Bibby, C.J. Bird Census Techniques; Elsevier: Amsterdam, The Netherlands, 2000; ISBN 0120958317.

59. Shriner, S. Distribution of Breeding Birds in Great Smoky Mountains National Park; North Carolina State University: Raleigh, NC, USA, 2001.

60. Brown, D.J.; Ferrato, J.R.; White, C.J.; Mali, I.; Forstner, M.R.J.; Simpson, T.R. Short-term changes in summer and winter resident bird communities following a high severity wildfire in a southern USA mixed pine/hardwood forest. For. Ecol. Manag. 2015, 350, 13-21. [CrossRef]

61. Reynolds, R.T.; Scott, J.M.; Nussbaum, R.A. A Variable circular-plot method for estimating bird numbers. Condor 1980, 82, 309-313. [CrossRef]

62. Marsden, S.J. Changes in Bird abundance following selective logging on Seram, Indonesia. Conserv. Biol. 1998, 12, 605-611. [CrossRef]

63. Reynaud, P.; Thioulouse, J. Identification of birds as biological markers along a neotropical urban-rural gradient (Cayenne, French Guiana), using co-inertia analysis. J. Environ. Manag. 2000, 59, 121-140. [CrossRef] 
64. Ellis, T.M.; Betts, M.G. Bird abundance and diversity across a hardwood gradient within early seral plantation forest. For. Ecol. Manag. 2011, 261, 1372-1381. [CrossRef]

65. Czeszczewik, D.; Zub, K.; Stanski, T.; Sahel, M.; Kapusta, A.; Walankiewicz, W. Effects of forest management on bird assemblages in the Bialowieza Forest, Poland. iForest-Biogeosci. For. 2015, 8, 377-385. [CrossRef]

66. Gunn, J.S.; Desrochers, A.; Marc-André, V.; Bourque, J.; Ibarzabal, J. Playbacks of Mobbing Calls of Black-Capped Chickadees as a Method to Estimate Reproductive Activity of Forest Birds. J. Field Ornithol. 2000, 71, 472-483. [CrossRef]

67. Roché, J.C. All the Bird Songs of Britain and Europe (Disc 4); Sittelle: Mens, France, 1993; Available online: https://www.discogs.com/Jean-C-Roch\%C3\%A9-All-The-Bird-Songs-Of-Britain-AndEurope/release/ 777634 (accessed on 16 April 2015).

68. Summers, R.W.; Jardine, D.C.; Marquiss, M.; Rae, R. The distribution and habitats of crossbills Loxia spp. in Britain, with special reference to the Scottish Crossbill Loxia scotica. Ibis 2002, 144, 393-410. [CrossRef]

69. Kasprzykowski, Z.; Goławski, A. Does the use of playback affect the estimates of numbers of Grey Partridge Perdix perdix? Wildl. Biol. 2009, 15, 123-129. [CrossRef]

70. Peterson, R.T.; Mountfort, G.; Hollom, P.A.D. Birds of Britain and Europe; Collins: New York, NY, USA, 2004; ISBN 0007192347.

71. Chang, Y.M. The Influence of avian aerial predator location on perceived predation risk and foraging location in five passerine species. J. Sci. Innov. 2013, 3, 97-111.

72. Turney, S.; Godin, J.J. To forage or hide? Threat-sensitive foraging behaviour in wild, non-reproductive passerine birds. Curr. Zool. 2014, 60, 719-728. [CrossRef]

73. Graw, B.; Manser, M.B. The function of mobbing in cooperative meerkats. Anim. Behav. 2007, 74, 507-517. [CrossRef]

74. Bates, D.; Maechler, M.; Bolker, B.; Walker, S. Fitting Linear Mixed-Effects Models Using lme4. J. Stat. Softw. 2015, 67, 1-48. [CrossRef]

75. Kreisel, K.; Stein, S. Bird use of burned and unburned coniferous forests during winter. Wilson Bull. 1999, 111, 243-250.

76. SPSS IBM SPSS Statistics. Available online: http://www-01.ibm.com/software/analytics/spss/products/ statistics/ (accessed on 27 October 2015).

77. Venier, L.A.; Fahrig, L. Habitat availability causes the species abundance-distribution relationship. Oikos 1996, 76, 564-570. [CrossRef]

78. Nana, D.E.; Sedlacek, O.; Dolezal, J.; Dancak, M.; Altman, J.; Svoboda, M.; Majesky, U.; Horak, D. Relationship between survival rate of avian artificial nests and forest vegetation structure along a tropical altitudinal gradient on Mount Cameroon. Biotropica 2015, 74, 758-764. [CrossRef]

79. Paz, U. Plants and Animals of the Land of Israel-Volume 6-Birds; Alon, A., Ed.; Ministry of Defence-Publishing: Tel Aviv, Israel; Society for the Protection of Nature in Israel: Tel Aviv, Israel, 1986.

80. Nijman, V. Seasonal variation in naturally occurring mobbing behaviour of drongos (Dicruridae) towards two avian predators. Artic. Ethol. Ecol. Evol. 2004, 16, 25-32. [CrossRef]

81. Bērzinšs, A.; Krama, T.; Krams, I.; Freeberg, T.M.; Kivleniece, I.; Kullberg, C.; Rantala, M.J. Mobbing as a trade-off between safety and reproduction in a songbird. Behav. Ecol. 2010, 21, 1054-1060. [CrossRef]

82. Krams, I.; Krama, T. Interspecific reciprocity explains mobbing behaviour of the breeding chaffinches, Fringilla coelebs. Proc. R. Soc. B 2002, 269, 2345-2350. [CrossRef]

83. Hinde, R.A. The behaviour of the Great Tit (Parus Major) and some other related species. Behav. Suppl. 1952, 2, 1-201.

84. Da Cunha, F.C.R.; Fontenelle, J.C.R.; Griessera, M. Predation risk drives the expression of mobbing across bird species. Behav. Ecol. 2017, 28, 1517-1523. [CrossRef]

85. Gottfried, B.M. Anti-predator aggression in birds nesting in old field habitats: An experimental analysis. Condor 1979, 81, 251-257. [CrossRef]

86. Griesser, M.; Ekman, J. Nepotistic mobbing behaviour in the Siberian jay, Perisoreus infaustus. Anim. Behav. 2005, 69, 345-352. [CrossRef]

87. Curio, E.; Klump, G.; Regelmann, K. An anti-predator response in the great tit (Parus major): Is it tuned to predator risk? Oecologia 1983, 60, 83-88. [CrossRef] [PubMed]

88. Gehlbach, F.R.; Leverett, J.S. Mobbing of Eastern Screech-Owls: Predatory cues, risk to mobbers and degree of threat. Condor 1995, 97, 831-834. [CrossRef] 
89. Lynch, J.F.; Morton, E.S.; Voort, M.E. Van der. Habitat segregation between the sexes of wintering Hooded Warblers (Wilsonia citrina). Auk 1985, 102, 714-721.

90. Kelset, M.G. A comparison of the song and territorial behaviour of a long-distance migrant, the Marsh Warbler Acrocephalus palustris, in summer and winter. Ibis 1989, 131, 403-414. [CrossRef]

91. Taku, A.I.; Evaristus, T.A.; Whytock, R.C.; Guilain, T.; Mallord, J. Habitat characteristics of wintering Wood Warbler Phylloscopus sibilatrix in the centre region of Cameroon: Conservation implications. Ostrich 2018, 89, 19-24.

92. Schwabl, H.; Kriner, E. Territorial aggression and song of male European Robins (Erithacus rubecula) in autumn and spring: Effects of antiandrogen treatment. Horm. Behav. 1991, 25, 180-194. [CrossRef]

93. Nocera, J.J.; Taylor, P.D.; Ratcliffe, L.M. Inspection of mob-calls as sources of predator information: Response of migrant and resident birds in the Neotropics. Behav. Ecol. Sociobiol. 2008, 62, 1769-1777. [CrossRef]

94. Randler, C.; Vollmer, C. Asymmetries in commitment in an avian communication network. Naturwissenschaften 2013, 100, 199-203. [CrossRef] [PubMed]

95. MacDicken, K.G.; Sola, P.; Hall, J.E.; Sabogal, C.; Tadoum, M.; de Wasseige, C. Global progress toward sustainable forest management. For. Ecol. Manag. 2015, 352, 47-56. [CrossRef]

96. Mitchell, M.S.; Lancia, R.A.; Gerwin, J.A. Using landscape-level data to predict the distribution of birds on a managed forest: Effects of scale. Ecol. Appl. 2001, 11, 1692-1708. [CrossRef]

97. Clawges, R.; Vierling, K.; Vierling, L.; Rowell, E. The use of airborne lidar to assess avian species diversity, density, and occurrence in a pine/aspen forest. Remote Sens. Environ. 2008, 112, 2064-2073. [CrossRef]

(C) 2019 by the authors. Licensee MDPI, Basel, Switzerland. This article is an open access article distributed under the terms and conditions of the Creative Commons Attribution (CC BY) license (http://creativecommons.org/licenses/by/4.0/). 